\title{
Enhance in-vitro rumen fermentation of Panicum maximum with biological supplements
}

\author{
Chathurika APS, Sujani S, Manawadu A and Seresinhe T \\ Department of Animal Science, Faculty of Agriculture, University of Ruhuna, Kamburupitiya, Sri Lanka \\ E-mail: sujani@ansci.ruh.ac.lk
}

(Received 12-04-2019; Revised10-05-2019; Accepted 13-06-2019)

\begin{abstract}
ABSTRAK
Chathurika APS, Sujani S, Manawadu A and Seresinhe T. 2019. Upaya meningkatkan fermentasi rumen Panicum maximum dengan suplemen biologis secara in vitro. JITV 24(2): 82-86. DOI.: http://dx.doi.org/10.14334.jitv.v24i2.1963

Akhir-akhir ini, penggunaan pakan suplemen biologis meningkat dibandingkan penggunaan pakan suplemen kimia. Tujuan objek penelitian ini adalah untuk mengevaluasi pengaruh pemberian suplemen rumput Panicum maximum. dengan dua spesies tanaman: Artocarpus heterophyllus (Jack leaves; AH) dan Tridax procumbens (TP) yang mengandung tanaman sekunder yang masing-masing dapat memetabolisme tannin dan saponin dan enzim yang memproduksi Dyadic Cellulase (CE) dan Ragi (YE). Dilakukan uji terhadap dua level perlakuan pada masing-masing suplemen. Untuk suplemen berbasis 20 (AHT1, TPT1) dan 30\% (AHT2 dan TPT2) tanaman disubtitusi dengan subtrat basa. Enzim yang digunakan adalah sebanyak $10 \mu \mathrm{l}$ (CET1) dan $20 \mu \mathrm{l}$ (CET2) serta ragi sebanyak 4 mg (YET1) dan 6 mg (YET2). Penelitian ini menggunakan Rancangan Acak Kelompok Lengkap (RAK) dengan lama inkubasi fermentasi in-vitro rumen selama 72 jam. Semua perlakuan secara nyata meningkatkan produksi gas in-vitro (PGIV) dibandingkan dengan kontrol. Perlakuan AH dan CE secara nyata meningkatkan degradibilitas bahan kering rumen in vitro (DBHIVR). Produksi nitrogen ammonia $\left(\mathrm{NH}_{3}-\mathrm{N}\right)$ tidak dipengaruhi oleh suplemen. Dapat disimpulkan bahwa perlakuan dalam penelitian ini memperkaya fermentasi rumen dalam hal PGIV dan DBHIVR dan mengurangi jumlah protozoa.
\end{abstract}

Kata Kunci: Artocarpus heterophyllus, Tridax procumbens, Selulase, Ragi, Protozoa, Fermentasi Rumen

\section{ABSTRACT}

Chathurika APS, Sujani S, Manawadu A and Seresinhe T. 2019. Enhance in-vitro rumen fermentation of Panicum maximum with biological supplements. JITV 24(2): 82-86. DOI.: http://dx.doi.org/10.14334.jitv.v24i2.1963

Recently the utilization of biological feed additives over chemical feed additives in animal feeds have increased. The objective of the present study was to evaluate the effect of supplementing wild guinea grass (Panicum maximum) with two plant species, artocarpus heterophyllus (jack leaves; ah) and tridax procumbens (TP) containing plant secondary metabolites tannin and saponin, respectively and the enzyme product dyadic cellulase (CE) and yeast (YE). For each suplement two levels of treatments were tested. In plant-based suplements 20 (AHT1, Tpt1) and 30\% (AHT2 and Tpt2) substituted the base substrate. The enzyme was applied as $10 \mu \mathrm{l}$ (CET1) and $20 \mu \mathrm{l}$ (CET2) and yeast as $4 \mathrm{mg}$ (YET1) and 6 mg (YET2). the experimental design was a randomized complete block design (RCBD) and the period of in vitro rumen fermentation incubation was 72 hrs. All treatments significantly $(\mathrm{P}<0.05)$ enhanced the in vitro gas production (IVGP) compared with the control. Treatments of ah and ce significantly $(\mathrm{P}<0.05)$ improved the in vitro rumen dry matter degradability (IVRDMD). All treatments significantly $(\mathrm{P}<0.05)$ suppressed the ruminal protozoa population as compared to the control. Ammonia nitrogen $(\mathrm{NH} 3-\mathrm{N})$ production was not significantly $(\mathrm{P}>0.05)$ influenced with supplements. in conclusion, treatments enhanced the rumen fermentation in means of enhanced IVGP, IVRDMD and reduced protozoa numbers.

Key Words: Artocarpus heterophyllus, Tridax procumbens, Cellulase, Yeast, Protozoa, Rumen Fermentation

\section{INTRODUCTION}

The gap between the nutrient requirement and the low nutrient availability combined with the poor digestibility of the commonly available feedstuffs is the major constraint against better performance and optimum production of ruminant animal in the tropics. One of the sustainable and widely distributed fodder species in the tropics is guinea grass which is characterized with several poor characteristics such as lower digestibility of the fiber fraction, drastic reduction of crude protein content with the maturity and low crude, suggests a need for supplementation. Enhancing the digestibility of fiber component of ruminant feedstuffs has been a huge research interest among ruminant nutritionists; thus various chemical, physical and microbiological methods have been introduced and some are being practically implemented. As evidenced by several studies, exogenous fibrolytic enzyme cellulase has several advantages in improving rumen fermentation parameters (Sujani et al. 2015). Despite the positive results gained with cellulase enzyme the relatively high cost and the less awareness have hindered the usage it under small-scale livestock farmers in tropics. This limitation has created an opportunity to research on less expensive and widely available biological supplements. In this backdrop utilization of plants and 
shrubs containing plant secondary metabolites and direct fed microbial, two biological approaches were tested. Supplementations of guinea grass with tree foliage containing plant secondary metabolites such as tannin and saponin were reported (Babayemi 2007) to improve the performance of ruminants. Yeast culture supplementation has been reported to enhance microbial growth and decrease $\mathrm{N}$ loss by incorporating more digestible carbohydrates into microbial mass (Sniffen et al. 2004). Therefore, the objective of the present study was to determine the effect of above-mentioned supplements on in vitro rumen fermentation parameters, in vitro gas production (IVGP), in vitro rumen dry matter degradability (IVRDMD), rumen protozoa population and ammonia nitrogen $\left(\mathrm{NH}_{3}-\mathrm{N}\right)$ production of wild guinea grass.

\section{MATERIALS AND METHODS}

\section{Substrate and supplement preparation}

Guinea grass (Panicum maximum), Artocarpus heterophyllus and Tridax procumbens were collected, dried $\left(55^{\circ} \mathrm{C}\right.$ for 48 hours) and ground to pass $1 \mathrm{~mm}$ screen. Other supplements were yeast (Saccharomyces cerevisiae) and Cellulase (CE) (E.C. 3.2.1.4,) produced by the fermentation of non-genetically modified organisms Trichoderma longibrachiatum. Proximate analysis of dry matter (DM) and crude protein (CP) were done according to the AOAC (1990).

\section{Treatment Allocation}

There are eight treatment combinations that will be compared with controls as presented in Table 1.

\section{Experimental design}

The experiment was carried out in a Randomized Complete Block Design (RCBD) with three replicates for each treatment and experiments were repeated twice.

\section{Statistical Analysis}

Analysis of variance (ANOVA) was performed on IVGP, IVRDMD, $\mathrm{NH}_{3}-\mathrm{N}, \mathrm{NDFD}$ and protozoa count with SPSS 20.0 statistics package and the statistical significance of the differences between means was tested using the Least Significant Difference (LSD). Descriptive analysis was done using Microsoft Excel 2010 version.

\section{In vitro gas production technique}

In vitro fermentation procedure and preparation of buffer and mineral solutions were done according to the procedures demonstrated by Menke \& Steingas (1988). Samples (base substrate and supplement) were accurately weighed into glass bottles $(120 \mathrm{ml})$.

For the in vitro incubation procedure, the medium of 11 volume was prepared with $2.5 \mathrm{~g}$ of tryptone (Sigma-Aldrich, Co., 3050 Spruce Street, St. Louis, MO, USA) dissolved in $500 \mathrm{ml}$ distilled water, 0.125 $\mathrm{ml}$ of micro mineral solution, $250 \mathrm{ml}$ of buffer solution and $1.25 \mathrm{ml}$ of $0.1 \%(\mathrm{w} / \mathrm{v})$ resazurin (Fluka AG, CH-9470 Buchs, Switzerland) solution. The medium was mixed in a container which kept in a water bath $\left(39^{\circ} \mathrm{C}\right)$ while bubbling $\mathrm{CO}_{2}$ through the solution for 45 minutes. L-cysteine hydrochloride (0.313 g) (Sigma-Aldrich, Co., 3050 Spruce Street, St. Louis, MO, USA) and sodium sulfide (0.313 g) (Park Scientific Limited, Northampton, UK) were directly added to the medium and further bubbled with $\mathrm{CO}_{2}$ for $15 \mathrm{~min}$. At this point, rumen fluid was collected from two donor heifers at the faculty farm (Faculty of Agriculture, University of Ruhuna, Kaburupitiya, Sri Lanka) through an esophageal suction method. Collected rumen fluid was transferred to a prewarmed flask and strained through four layers of cheese cloth. All the laboratory handlings of rumen fluid were carried out under a continuous flow of $\mathrm{CO}_{2}$ and $39^{\circ} \mathrm{C}$ of temperature. Prepared rumen fluid was added to the medium in a ratio of 1:4 (rumen fluid: medium) and flushing of $\mathrm{CO}_{2}$ was continued until the solution turned to grey or clear, after which $42 \mathrm{ml}$ of medium were pipetted into each incubation bottle, containing the pre-incubated substrate, and the bottles were immediately crimp sealed with a rubber stopper and placed in the water bath with shaker at $39^{\circ} \mathrm{C}$.

\section{Measurements and data collection}

In vitro gas production was recorded at $3,6,9,12$, 24, 48 and $72 \mathrm{~h}$ within the incubation period. After 72 $\mathrm{h}$, bottles were removed from the shaker and placed on ice to terminate the reaction. Remaining solid portions were separately prepared to determine IVRDMD and NDFD while the aliquots of the filtrates were stored at $20^{\circ} \mathrm{C}$ until analyzed for $\mathrm{NH}_{3}-\mathrm{N}$ and protozoan count (by mixing $1 \mathrm{ml}$ of the filtrate with a $1 \mathrm{ml}$ of $40 \%$ (w/v) formaldehyde).

\section{Chemical Analysis}

At the end of incubation, solid portions were separately analyzed to determine IVRDMD with oven 
Tabel 1. Combination Of Treatment

\begin{tabular}{llcc}
\hline \hline Treatment & Level of treatment & Amount of treatment (mg) & Amount of base substrate (Panicum maximum) (mg) \\
\hline AHT1 & Artocarpus heterophyllus (20\%) & $100 \mathrm{mg}$ & $400 \mathrm{mg}$ \\
AHT2 & Artocarpus heterophyllus (30\%) & $150 \mathrm{mg}$ & $350 \mathrm{mg}$ \\
TPT1 & Tridax procumbens (20\%) & $100 \mathrm{mg}$ & $400 \mathrm{mg}$ \\
TPT2 & Tridax procumbens (30\%) & $150 \mathrm{mg}$ & $350 \mathrm{mg}$ \\
CET1 & Cellulase (CE) & $10 \mu \mathrm{l}$ & $500 \mathrm{mg}$ \\
CET2 & Cellulase (CE) & $20 \mu \mathrm{l}$ & $500 \mathrm{mg}$ \\
YET1C & Yeast (YE) & $4 \mathrm{mg}$ & $500 \mathrm{mg}$ \\
YET2C & Yeast (YE) & $6 \mathrm{mg}$ & $500 \mathrm{mg}$ \\
Control & - & - & $500 \mathrm{mg}$ \\
\hline
\end{tabular}

dry method $\left(55^{\circ} \mathrm{C}, 48\right.$ hours $)$ and NDFD was estimated following methods of Van Soest (1963). Liquid portion was analyzed for $\mathrm{NH}_{3}-\mathrm{N}$ (Kjeltec System 1002, Tecator AB, Hoganas, Sweden) (AOAC 1990) and protozoa were counted with Burker type hemocytometre (0.1 and $0.02 \mathrm{~mm}$ depth, respectively; Blau Brandw, Wertheim, Germany). Triplicate preparations of each sample were counted

\section{RESULTS AND DISCUSSION}

\section{Result}

The chemical composition of substrate Guinea Grass and plants which supplied supplements are presented in Table 2. Data on IVGP, IVRDMD, $\mathrm{NDFD}, \mathrm{NH}_{3}-\mathrm{N}$ and protozoa count are presented in Table 3. IVGP supplemented with AHT1, AHT2, TPT1, YET1, YET2 and CET2 was significantly higher when compared with control.

Only CE and AHT2 could significantly increase the IVRDMD where upper levels of $\mathrm{AH}$ and TP significantly reduce the NDFD. No significant difference was observed in $\mathrm{NH}_{3}-\mathrm{N}$ production with any treatment. With all treatments protozoa count was significantly reduced.

\section{Discusion}

Gas measurement provides a useful data on digestion kinetics of both soluble and insoluble fractions of feedstuffs as it helps to better quantify nutrients utilization hence a good indicator of digestibility, fermentability, and microbial protein production (Getachew et al. 1998). Referring to the Figure 1, it could be assumed that accelerated initial IVGP upto 3 hours of incubation could be due to the stimulation of initial phase degradation of substrate (Giraldo et al. 2007). When consider all supplements it was observed that there was a drop in gas production with $\mathrm{AH}$ and $\mathrm{TP}$ supplements and it suggests a negative effect of tannin and saponin on in vitro gas production whereas $\mathrm{CE}$ showed a positive effect on in vitro gas production and it would be the most likely mode of action of enzyme. Finding on the negative relationship between phenolics and dry matter degradation is in line with the present results where a high level of saponin (TPT2) significantly reduced the IVRDMD. The effectiveness of yeast addition on in vitro fermentation parameters showed inconsistencies in previous studies. Mutsvangwa et al. (1992) reported that in vitro GP of a barley diet for beef cattle supplemented with yeast culture (YeaSacc1026) was lower than that in the control, while Tang et al. (2008) found that supplementation of yeast culture (Original XP; Diamond V Mills Inc., Cedar Rapids, IA, USA) increased the cumulative GP and present results are consistent with the latter finding. Differences in the yeast species derived from may be the main reason for discrepancies in results whereas fermentation substrate and experimental conditions could also contribute. Significantly enhanced IVGP upon the supplementation of CE was reported by Eun \& Beauchemin (2007) and in contrary Giraldo et al. (2007) found that there was no significant effect of enzyme supplementation on IVGP of a fibrous diet. As suggested by a previous study of Colombatto \& Beauchemin (2003), enzymes could enhance IVRDMD by removing structural barriers and facilitating microbial colonization resulting the increased rate of degradation, which is consistent with current research results.

Dietary protein is fermented in the rumen to simpler $\mathrm{N}$ compounds and reincorporated; primarily as $\mathrm{NH}_{3}-\mathrm{N}$ which acts as an indicator of microbial nitrogen synthesis. As $\mathrm{NH}_{3}-\mathrm{N}$ is the primary $\mathrm{N}$ source of most ruminal organisms increased $\mathrm{NH}_{3}-\mathrm{N}$ could be resulted from improved microbial activities. Fadel Elseed et al. (2007) reported yeast (S. cerevisiae) supplementation resulted in a numerical increase in ammonia-N concentration in rumen fluid of Nubian goat's kids through any change could not be observed in the present study. Wang et al. (2001) found that no effect of fibrolytic enzyme supplementation on ruminal $\mathrm{NH}_{3}-\mathrm{N}$ production under in vitro conditions and present results agree with the findings. 
Table 2. Chemical Composition of Substrate Guinea Grass (Panicum Maximum) And Supplements

\begin{tabular}{lccc}
\hline \hline Substrate & DM $(\mathrm{g} / \mathrm{kg})$ & $\mathrm{CP}(\mathrm{g} / \mathrm{kg} \mathrm{DM})$ & $\mathrm{NDF}(\mathrm{g} / \mathrm{kg} \mathrm{DM})$ \\
\hline Panicum maximum & $283 \pm 3.37$ & $214.0 \pm 4.30$ & $619 \pm 6.50$ \\
Artocarpus heterophyllus & $202 \pm 2.25$ & $221.1 \pm 0.31$ & $342 \pm 5.61$ \\
Tridax procumbens & $268 \pm 10.21$ & $345.7 \pm 0.05$ & $495 \pm 7.21$ \\
\hline
\end{tabular}

Table 3. Cumulative in vitro gas production (IVGP), in vitro rumen dry matter disappearance (IVRDMD), neutral detergent fiber disappearance (NDFD), ammonia nitrogen $\left(\mathrm{NH}_{3}-\mathrm{N}\right)$ production and protozoan count and of guinea grass (Panicum maximum) in response to the treatments.

\begin{tabular}{lccccc}
\hline \hline Treatment & IVGP (ml/ 500 mg DM/72 hr) & IVRDMD \% & NDFD \% & NH $_{3}-\mathrm{N} \mathrm{mg} / 100 \mathrm{ml}$ & Protozoa Count/1ml \\
\hline AHT1 & $75 \pm 0.38^{\mathrm{b}}$ & $69.43 \pm 1.07^{\mathrm{a}}$ & $52.14 \pm 1.87^{\mathrm{b}}$ & $44.71 \pm 0.34^{\mathrm{a}}$ & $5556 \pm 103^{\mathrm{b}}$ \\
AHT2 & $75 \pm 0.45^{\mathrm{b}}$ & $71.97 \pm 1.42^{\mathrm{d}}$ & $46.25 \pm 1.53^{\mathrm{c}}$ & $42.16 \pm 2.89^{\mathrm{a}}$ & $7778 \pm 111^{\mathrm{b}}$ \\
TPT1 & $76.5 \pm 0.87^{\mathrm{b}}$ & $69.43 \pm 0.86^{\mathrm{a}}$ & $50.82 \pm 1.80^{\mathrm{b}}$ & $45.56 \pm 1.02^{\mathrm{a}}$ & $6667 \pm 222^{\mathrm{b}}$ \\
TPT2 & $72 \pm 2.24^{\mathrm{a}}$ & $63.10 \pm 2.91^{\mathrm{e}}$ & $52.14 \pm 1.45^{\mathrm{b}}$ & $45.90 \pm 0.85^{\mathrm{a}}$ & $3333 \pm 98^{\mathrm{c}}$ \\
YET1 & $75.5 \pm 0.29^{\mathrm{b}}$ & $68.97 \pm 0.60^{\mathrm{a}}$ & $52.06 \pm 1.78^{\mathrm{b}}$ & $44.37 \pm 2.21^{\mathrm{a}}$ & $4444 \pm 210^{\mathrm{c}}$ \\
YET2 & $78.5 \pm 0.36^{\mathrm{c}}$ & $69.33 \pm 0.37^{\mathrm{a}}$ & $54.08 \pm 2.10^{\mathrm{a}}$ & $46.41 \pm 0.51^{\mathrm{a}}$ & $3333 \pm 86^{\mathrm{c}}$ \\
CET1 & $73 \pm 1.25^{\mathrm{a}}$ & $73.47 \pm 2.42^{\mathrm{b}}$ & $56.20 \pm 3.97^{\mathrm{a}}$ & $47.09 \pm 5.95^{\mathrm{a}}$ & $6667 \pm 133^{\mathrm{b}}$ \\
CET2 & $80.5 \pm 1.83^{\mathrm{c}}$ & $71.93 \pm 2.89^{\mathrm{c}}$ & $54.66 \pm 3.57^{\mathrm{a}}$ & $45.39 \pm 1.87^{\mathrm{a}}$ & $6667 \pm 104^{\mathrm{b}}$ \\
Control & $73 \pm 0.79^{\mathrm{a}}$ & $67.80 \pm 0.94^{\mathrm{a}}$ & $54.51 \pm 1.95^{\mathrm{a}}$ & $45.73 \pm 2.72^{\mathrm{a}}$ & $12222 \pm 276^{\mathrm{a}}$ \\
\hline
\end{tabular}

Values are means of three replicates $\pm \mathrm{SE}$. The significance of means was considered at $\mathrm{p}<0.05$.

AHT1 $=20 \% \mathrm{AH} \quad$ TPT1 $=20 \% \mathrm{TP} \quad$ YET1 $=4 \mathrm{mg} \quad$ CET1 $=10 \mu \mathrm{l}$

AHT2 $=30 \% \mathrm{AH} \quad \mathrm{TPT} 2=30 \% \mathrm{TP} \quad$ YET2 $=6 \mathrm{mg} \quad$ CET2 $=20 \mu \mathrm{l}$
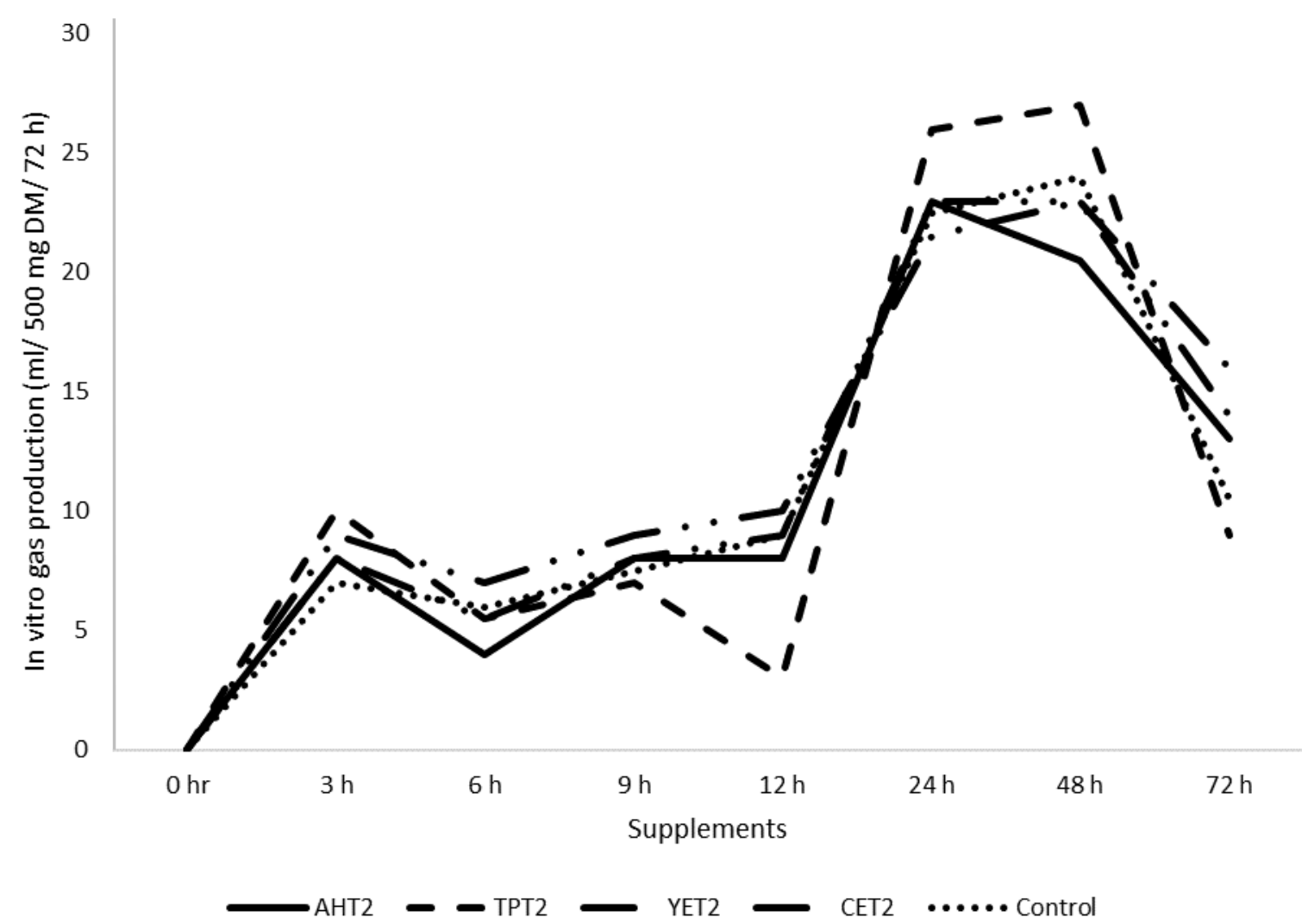

Figure 1. In vitro gas production of higher level of supplement of each supplement over 72 hours 
Some studies have indicated that removal of the protozoal population from the rumen (defaunation) may lower the amount of hydrogen in the system and thereby reduce methane production. Methane production can be decreased by $61 \%$ in defaunated rumen fluid (Iqbal et al. 2008). The findings of above researches suggest that the reduced ruminal protozoa population may tends to reduce the methane production. Hence the significantly reduced protozoan count in the present study provides a strong indicator of possible suppression of enteric methane production though it was not measured in the present study.

\section{CONCLUSION}

It can be concluded that the supplementation of guinea grass (Panicum maximum) with Artocarpus heterophyllus (Jak leaves) Tridax procumbens, cellulase enzyme and yeast significantly enhanced in vitro total gas production and significantly suppressed the protozoan count. Rumen ammonia nitrogen production was not influenced upon supplementations and in some instances in vitro rumen dry matter disappearance and neutral detergent fiber disappearance were increased significantly.

\section{REFERENCES}

AOAC. 1990. Official Methods of Analysis. 15th ed. Association of Official Analytical Chemists, Arlington. Helrich K, editor. Virginia (USA): Association of Official Analytical Chemists Inc.

Babayemi O. 2007. In vitro fermentation characteristics and acceptability by West African dwarf goats of some dry season forages. Afr J Biotechnol. 6:1260-1265.

Colombatto D, Beauchemin K. 2003. A proposed methodology to standardize the determination of enzymic activities present in enzyme additives used in ruminant diets. Can J Anim Sci. 83:559-568.

Eun J, Beauchemin K. 2007. Assessment of the efficacy of varying experimental exogenous fibrolytic enzymes using in vitro fermentation characteristics. Anim Feed Sci Technol. 132:298-315.

Fadel Elseed A, Rania, Abusamra M. 2007. Effects of supplemental yeast (Saccharomyces cerevisiae) culture on NDF digestibility and rumen fermentation of forage sorghum hay in Nubian goat's kids. Res J Agric Biol Sci. 3:133-137.

Getachew G, Blümmel M, Makkar H, Becker K. 1998. In vitro gas measuring techniques for assessment of nutritional quality of feeds: a review. Anim Feed Sci Technol. 72:261-281.

Giraldo L, Tejido M, Ranilla M, Carro M. 2007. Effects of exogenous cellulase supplementation on microbial growth and ruminal fermentation of a high-forage diet in Rusitec fermenters1. J Anim Sci. 85:1962-1970.

Iqbal MF, Cheng Y-F, Zhu W-Y, Zeshan B. 2008. Mitigation of ruminant methane production: current strategies, constraints and future options. World J Microbiol Biotechnol. 24:2747-2755.

Menke H, Steingas H. 1988. Estimation of the energetic feed value obtained from chemical analysis and gas production using rumen fluid. Anim Res Dev. 28:7-55.

Mutsvangwa T, Edwards I, Topps J, Paterson G. 1992. The effect of dietary inclusion of yeast culture (Yea-Sacc) on patterns of rumen fermentation, food intake and growth of intensively fed bulls. Anim Sci. 55:35-40.

Sniffen C, Chaucheyras Durrand F, de Ondarza M, Donaldson G. 2004. Predicting the impact of live yeast strain on rumen kinetics and ration formulation. In: Proc 19th Annu Southwest Nutr Manag Conf Tempe, Arizona, Febr 2627 2004. Arizona (USA); p. 53-60.

Van Soest P. 1963. Use of detergents in the analysis of fibrous feeds. II. A rapid method for determination of fiber and lignin. J AOAC. 46:829-835.

Sujani S, Pathirana I, Seresinhe T. 2015. Enhanced in vitro fermentation parameters of guinea grass ecotype "A" (Panicum maximum) and rice straw (Oryza sativa) with supplementation of exogenous fibrolytic enzymes. Livest Res Rural Dev. 27.

Tang S, Tayo G, Tan Z, Sun Z, Shen L, Zhou CS, Xiao WJ, Ren GP, Han XF, Shen SB. 2008. Effects of yeast culture and fibrolytic enzyme supplementation on in vitro fermentation characteristics of low-quality cereal straws1. J Anim Sci. 86:1164-1172.

Wang Y, McAllister T, Rode L, Beauchemin K, Morgavi D, Nsereko V, Iwaasa A, Yang W. 2001. Effects of an exogenous enzyme preparation on microbial protein synthesis, enzyme activity and attachment to feed in the Rumen Simulation Technique (Rusitec). Br J Nutr. 85:325-32. 